НАУКОВИЙ ВІСНИК

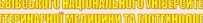
2. 111 InIM (1)

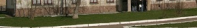
TRIES: FOOD Том 21 № 92 2019

\section{Науковий вісник Дьвівського національного університету} ветеринарної медицини та біотехнологій імені С.3. Гжицького. Серія: Харчові технологіі

\author{
Scientific Messenger of Lviv National University
} of Veterinary Medicine and Biotechnologies.

Series: Food Technologies

UDC 637.344 .8

\title{
Technology of low allergenic milk with whey proteins hydrolysate
}

\author{
V.G. Yukalo, K.Ye. Datsyshyn \\ Ternopil Ivan Pul'uj National Technical University, Ternopil, Ukraine
}

Article info

Received 04.09.2019

Received in revised form 03.10 .2019

Accepted 04.10.2019

Ternopil Ivan Pul'uj National Technical University, Ruska Str., 56 Ternopil, 46001, Ukraine. Tel.: +38-067-358-80-00 E-mail: biotech@tu.edu.te.ua

Yukalo, V.G., \& Datsyshyn, K.Ye. (2019). Technology of low allergenic milk with whey proteins hydrolysate. Scientific Messenger of Lviv National University of Veterinary Medicine and Biotechnologies. Series: Food Technologies, 21(92), 14-18. doi: 10.32718/nvlvet-f9203

In recent years, there has been a steady increase in the number of various allergic diseases in children and adults. Clinical manifestations of allergic reactions can be observed almost from infancy, which is often associated with nutrition specificity. It is proved that one of the strongest milk allergens are the main whey fractions $\beta$-lactoglobulin and $\alpha$-lactalbumin. One way to reduce allergies is to remove or completely replace whey proteins. Another way to reduce allergenicity is to use whey protein hydrolysates. In most cases, hydrolysates are obtained using cheap active proteolytic preparations. They usually have wide specificity, and the hydrolysates formed by them include short peptides with low allergenicity. Numerous biologically active peptides which have a positive effect on the organism are either lost or the possibility of their formation is reduced in such cases. A valuable source of such biologically active peptides is whey proteinprecursors. Therefore, the purpose of the research is to develop a technology of low-allergenic milk with the preservation of natural biologically active peptides from whey proteins. The concentrate of natural casein was obtained in the result of the «milk-pectin-water» system dividing for creating a low-allergenic product. The fractional composition of the casein complex and milk whey proteins was analyzed by polyacrylamide gel electrophoresis. Whey protein concentrate was used as the substrate to obtain the hydrolysate. Proteolysis was performed with pancreatin at $37^{\circ} \mathrm{C}$ and $\mathrm{pH}$ 7.9. The composition of the obtained hydrolysate was analyzed by gel filtration on Sephadex G-25. The peptides and polypeptides composition of hydrolysate was characterizated with the help of express electrophoresis. The technology of the proposed dairy product includes addition to a liquid concentrate of natural casein the whey protein hydrolysate obtained in physiological conditions. The results of electrophoretic and chromatographic researches indicate about the absence of main proteins allergens from milk whey in the product. This allows recommending it for the nutrition of people allergic to whey proteins.

Key words: whey proteins, milk whey proteins hydrolysate, concentrate of micellar casein, proteolysis, low allergenic product.

\section{Технологія низькоалергенного молока 3 гідролізатом білків сироватки}

\author{
В.Г. Юкало, К.Є. Дацишин
}

Тернопільський національний технічний університет імені Івана Пулюя, м. Тернопіль, Украӥна

В останні роки спостерігається невпинне зростання кількості різноманітних алергічних захворювань у дітей $і$ дорослих. Клінічні прояви алергічних реакцій можуть спостерігатися практично з грудного віку, шо пов'язано найчастіше з особливостями харчування. Доведено, що одними з найсильніших алергенів молока $\epsilon$ основні фракцї сироватки $\beta$-лактоглобулін та $\alpha-$ лактальбумін. Одним із шляхів зниження алергії є видалення або повна заміна білків сироватки молока. Іншим шляхом зниження алергенності є використання гідролізатів сироваткових білків. В більшості випадків гідролізати отримують з використанням дешевих активних протеолітичних препаратів. Вони зазвичай володіють иирокою специфічністю, а утворені за їх допомогою гідролізати включають короткі пептиди із низькою алергенністю. В таких випадках або повністю втрачається, або знижується імовірність утворення численних біологічно активних пептидів, які позитивно впливають на організм. Цінним джерелом таких біологічно активних пептидів є білки-попередники з сироватки молока. Тому метою роботи є розробка технологї низькоалергенного молока зі збереженням природніх біологічно активних пептидів із білків сироватки. Для створення низькоалергенного продукту нами було отримано концентрат нативного казеїну в результаті розшарування системи “молоко-пектин-вода”. Фракційний 
склад білків казеїнового комплексу та сироватки молока аналізували електрофорезом в поліакриламідному гелі. Як субстрат для отримання гідролізату використовували концентрат сироваткових білків. Протеоліз проводили панкреатином при температурі $37{ }^{\circ} \mathrm{C}$ та рН 7,9. Склад отриманого гідролізату аналізували гель-фільтрацією на сефадексі G-25. 3 а допомогою експреселектрофорезу була проведена очінка гідролізату за складом пептидів та поліпептидів. В технології запропонованого нами молочного продукту, передбачається внесення гідролізату білків сироватки молока, шуо отриманий у фізіологічних умовах, до рідкого кониентрату нативного казеїну. Отримані електрофоретичні та хроматографічні дослідження свідчать про відсутність в отриманому продукті основних білків-алергенів з сироватки молока. Це дозволяє рекомендувати його для харчування людей з алергією на білки сироватки.

Ключові слова: протеїни сироватки молока, гідролізат білків сироватки молока, концентрат нативного казеїну, протеоліз, низькоалергенний продукт.

\section{Вступ}

За даними епідеміологічних досліджень від $0,6 \%$ до $3 \%$ дітей до 6 років, $0,3 \%$ старших дітей та підлітків і 0,5\% дорослих страждають алергією на коров'яче молоко. Більшість дітей, що страждають алергією на молоко переростають іï, стаючи здатними споживати молоко та молочні продукти, хоча $15 \%$ хворих залишаються алергічними протягом усього дорослого життя (Kim et al., 2018). Доведено, що одними 3 найсильніших алергенів молока є основні фракції сироватки $\beta$-лактоглобулін ( $\beta-L G)$ та $\alpha$-лактальбумін $(\alpha-\mathrm{LA})$. Значно рідше в літературі описано алергію на інші білки молочної сироватки, такі як імуноглобулін (IG), альбумін сироватки (BSA) або лактоферин (LF) (Villa et al., 2018). Одним зі шляхів зниження алергії $€$ видалення або повна заміна білків сироватки молока. У цьому випадку використовують інші харчові неалергенні білки. Ще одним способом зниження алергенності є використання гідролізатів сироваткових білків. Проте аналіз літератури показує, що в більшості випадків такі гідролізати отримували 3 використанням дешевих активних протеолітичних препаратів, для яких характерна широка специфічність дії (Khramtsov, 2011). Утворені за їхньою допомогою гідролізати включають короткі пептиди із низькою алергенністю.

В останні десятиліття показано, що білки сироватки молока $\beta$-LG, $\alpha$-LA та в меншій мірі інші фракції $є$ попередниками численних біологічно активних пептидів. 3 різних білків сироватки молока можуть утворюватись антигіпертензивні пептиди, антагоністи опіатних рецепторів, регулятори моторики кишківника, імуномодуляторні та антимікробні пептиди. Також відкриті нові види біоактивних пептидів, які виявляють антиканцерогенну та антиоксидантну дію, знижують рівень холестеролу в крові, регулюють апетит, впливають на засвоєнная кальцію (Iukalo et al., 2013). Майже всі природні біоактивні пептид из білків сироватки молока були отримані за дії травних протеаз у фізіологічних умовах (Fox et al., 2015). При використанні активних протеолітичних препаратів 3 широкою специфічністю переважно мікробіологічного походження імовірність утворення природніх БАП в отриманих низькоалергенних гідролізатах сироваткових білків низька. Це загалом знижує біологічну цінність кінцевого продукту. Тому з метою збереження природніх БАП перспективним може бути низькоалергенний молочний продукт, отриманий комбінацією нативного казеїну з гідролізатом сироваткових білків. При цьому гідролізат повинен бути отриманим за дії травних протеаз у фізіологічних умовах. Важливим при створенні такого молочного продукту є те, що гідролізати білків сироватки на відміну від казеїнових, не мають вираженого гіркого присмаку. У такому продукті будуть наявні казеїнові попередники БАП та природні БАП з протеїнів сироватки молока і відсутні основні алергени з сироватки молока.

Мета. Розробка технології низькоалергенного молока зі збереженням природніх біологічно активних пептидів із білків сироватки.

\section{Матеріал і методи досліджень}

В роботі використовували свіже знежирене молоко кислотністю $18-19^{\circ}$ Т. Для проведення протеолізу був взятий ферментний препарат панкреатин виробництва ПрАТ “Технолог” (Україна). Як субстрат для отримання гідролізату було використано концентрат сироваткових білків (КСБ), вироблений на ТОВ “Бучацький сирзавод” (Україна) згідно 3 проектом ТУ У 15.5-00419880-ХХХ:2011 "Концентрат сироваткових білків (КСБ-УФ). Технічні умови”. Концентрат нативного казеїну (КНК) отримували відповідно до ТУ 49 1169-85. При цьому було використано цитрусовий пектин, що відповідає ДСТУ 6088: 2009. Загальний казеїн виділяли зі свіжого знежиреного молока шляхом подвійного переосадження при $\mathrm{pH}$ 4,6. Виділення казеїну супроводжувалось інактивацією природних протеаз шляхом екстракції в оцтовій кислоті при $\mathrm{pH}$ 4,0. Сироватку молока виділяли після ізоелектричного осадження казеїнів. Казеїни відділяли центрифугуванням. Отриману сироватку відцентрифуговували двічі на центрифузі ОПН-8 (5000 об/хв, 15 хв). Концентрацію казеїнів та протеїнів сироватки молока визначали спектрофотометрично за поглинанням при довжині хвилі $\lambda=280$ нм. При цьому використовували коефіцієнти поглинання $\left(D_{1 c m}^{1 \%}\right): 12,3$ - для білків сироватки молока; 8,2 - для загального казеїну. Фракційний склад білків казеїнового комплексу та сироватки молока аналізували електрофорезом в поліакриламідному гелі (ПАГ). Для аналізу білків сироватки використовували аналітичний диск-електрофорез в нативних умовах в трубочках поліакриламідного гелю (Yukalo et al., 2018). Диск-електрофорез проводили в апараті фірми "Reanal" (Угорщина). Для аналізу гідролізатів концентрату КСБ використовували розроблений нами метод експрес-електрофорезу на пластинках однорідного ПАГ. Експрес-електрофорез проводили на апараті типу Стадієра (Yukalo et al., 2019). Аналіз складу білків казеїнового комплексу проводили в вертикальних пластинках однорідного ПАГ за наявності сечо- 
вини (Yukalo et al., 2018). Електрофореграми фіксували в 7\% оцтовій кислоті і забарвлювали $0,5 \%$ амідо чорний 10 В. Електрофоретичні гелі та буфери готували 3 використанням реактивів фірми "Reanal" (Угорщина). Гель-фільтрацію продуктів протеолізу сироваткових білків проводили на колонці $з$ набору для рідинної хроматографії фірми “Reanal” (Угорщина). При цьому був використаний сефадекс G-25 фірми "Рharmacia" (Швеція). В готовому продукті визначали органолептичні показники: зовнішній вигляд та консистенцію, смак, запах і колір.

\section{Результати та їх обговорення}

Для створення низькоалергенного продукту нами було отримано КНК в результаті розшарування системи “молоко-пектин-вода". Для оцінки процесу виділення КНК нами були відібрані проби з верхньої полісахаридної фази і нижньої білкової фази після розшарування системи. Результати аналізу фракційного складу білків обох фаз показані на рис. 1.

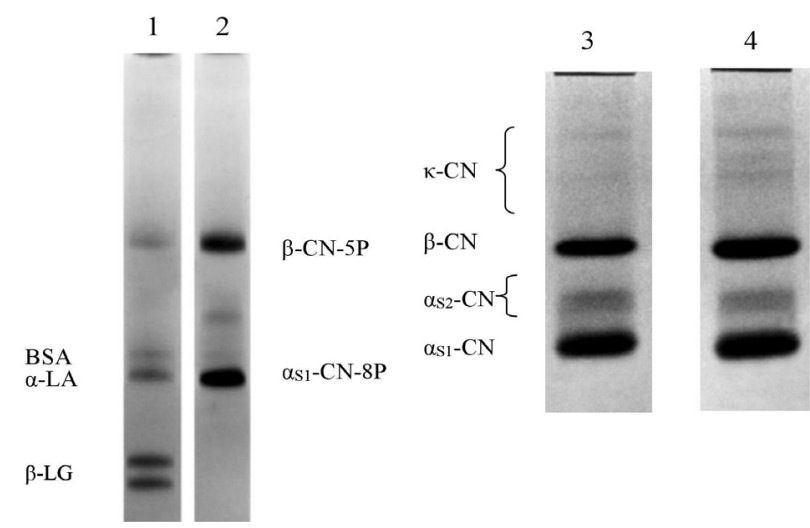

Рис. 1. Електрофореграми, отримані в результаті аналітичного диск-електрофорезу білків полісахаридної фази (1) та білків загального казеїну (2). Електрофореграми, отримані в результаті однорідного електрофорезу за наявності сечовини загального казеїну

(3) та концентрату нативного казеїну (4)

Оскільки білки казеїнового комплексу і білки сироватки молока суттєво відрізняються своїми фізикохімічними властивостями, нами було використано дві електрофоретичні системи для їх аналізу (McSweeney \& Fox, 2013). Білки казеїну ефективно розділяються в однорідному ПАГ за наявності сечовини. Всі основні фракції сироватки молока виявляються при застосуванні диск-електрофорезу в нативних умовах для нейтральних і кислих білків. При комбінації цих методів ми отримали об'єктивний аналіз розподілу білкових фракцій молока у полісахаридній і білковій фазі після розшарування системи “молоко-пектин-вода". Результати електрофорезу свідчать, що в полісахаридну фазу переходять всі основні алергени сироватки молока ( $\beta$-LG, $\alpha$-LA, IG, BSA, LF), а також нова неідентифікована білкова фракція з низькою електрофоретичною рухливістю. Порівняння іiі з електрофореграмою загального казеїну, отримано. дискелектрофорезом (рис. 1(2), свідчить, що це може бути казеїнова фракція $\beta-\mathrm{CN}-5 \mathrm{P}$. Відомо, що ця казеїнова фракція може виходити із складу міцел при низьких температурах (Fox et al., 2015). Аналіз складу білкової фази (рис. 1(3) свідчить про наявність в ній всіх фракцій білків казеїнового комплексу, серед яких є основні попередники БАП казеїнового походження (рис. 1(4). Алергенів з сироватки молока в білковій фазі не виявлено.

Для отримання гідролізату було використано 15\% розчин КСБ. Гідроліз КСБ проводили в фізіологічних умовах $\left(37^{\circ} \mathrm{C}, \mathrm{pH} 7,9\right)$ панкреатином при співвідношенні ензим: субстрат 1:20. Ефективність такого співвідношення доведена раніше (Dekusha, 2009). Склад отриманого гідролізату аналізували гель-фільтрацією на сефадексі G-25. У відібраних для гель-фільтрації взірцях гідролізату осаджували нерозщеплені білки 5\% трихлороцтовою кислотою. Результати гельфільтрації показані на рис. 2. На хроматограмі видно типовий молекулярно-масовий розподіл продуктів протеолізу КСБ панкреатином.

Близько 85\% продуктів протеолізу мають молекулярну масу менше ніж 5000 Да, в тому числі близько 40\% - менше ніж 1000 Да. Також для характеристики гідролізату були взяті проби для електрофоретичного експрес-аналізу. Такий аналіз дозволяє оцінити склад протеїнів і поліпептидів. Результати аналізу показані на рис. 3. На електрофореграмі КНК (рис. 3(1) видно основні білки-алергени з сироватки молока. У взірці гідролізату, взятого без осадження білків трихлороцтовою кислотою, практично відсутні високомолекулярні білки і поліпептиди. На електрофореграмі можна помітити лише їхні сліди.

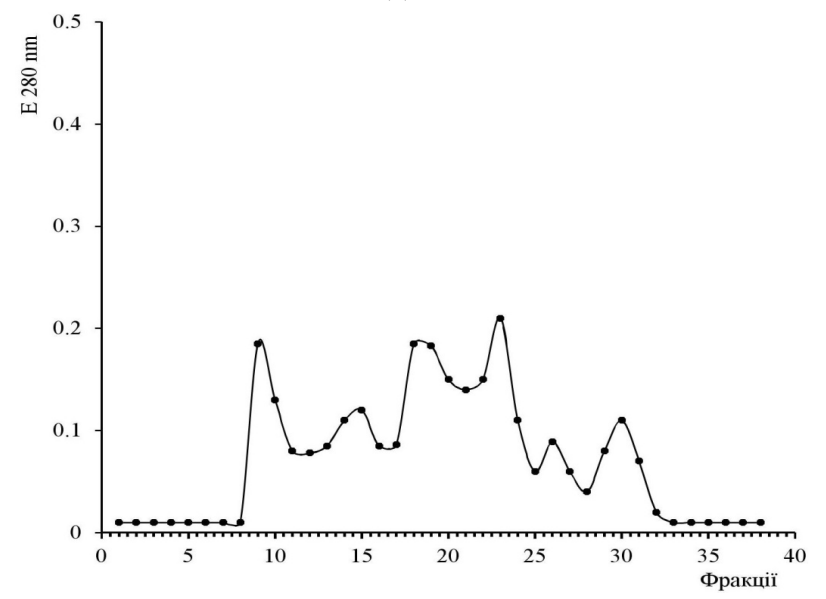

Рис. 2. Хроматограма панкреатинового гідролізату концентрату сироваткових білків, отримана гель-фільтрацією на сефадексі G-25 12

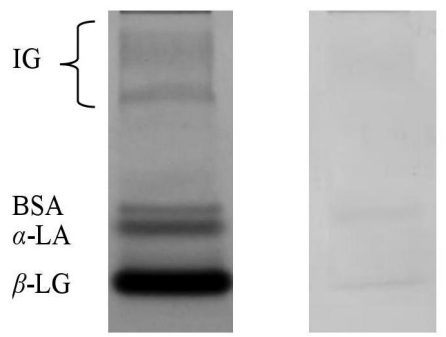

Рис. 3. Електрофореграми, отримані в результаті експрес-електрофорезу сироватки молока (1) та панкреатинового гідролізату КСБ 
Низькомолекулярні продукти протеолізу не фіксуються в поліакриламідному гелі. Таким чином у другому компоненті (гідролізат КНК), що використовується для створення продукту, відсутні білки алергени з сироватки молока.

Технологія виготовлення низькоалергенного продукту з гідролізатом білків сироватки молока включає:

- отримання концентрату нативного казеїну за ТУ;

- отримання гідролізату сироваткових білків;

- змішування і пастеризація суміші.

Основні етапи технології виробництва низькоалергенного продукту показані на рис. 4. При його виробництві важливим є чітке дотримання технічних умов виготовлення КНК, оскільки зниження $\mathrm{pH}$ його розчину може призводити до появи осаду.

Отримане низькоалергенне молоко з гідролізатом білків сироватки характеризували за органолептичними показниками. Результати дегустаційної оцінки показані у таблиці 1.

\section{Таблиця 1}

Органолептичні показники низькоалергенного молока з гідролізатом білків сироватки

\begin{tabular}{|c|c|}
\hline $\begin{array}{c}\text { Найменування } \\
\text { показника }\end{array}$ & Характеристика \\
\hline $\begin{array}{l}\text { Зовнішній вигляд } \\
\text { і консистенція }\end{array}$ & Однорідна рідина, без осаду. \\
\hline Смак і запах & $\begin{array}{l}\text { Характерний присмак пастеризації } \\
\text { та незначний альбумінний присмак, } \\
\text { що залежить від кількості внесеного } \\
\text { гідролізату }\end{array}$ \\
\hline Колір & Колір білий з жовтуватим відтінком. \\
\hline
\end{tabular}

Показники зовнішнього вигляду, консистенції, смаку є характерними для молочних продуктів даної групи. Наведені у таблиці 1 характеристики свідчать про те, що використання гідролізату білків сироватки суттєво не змінює органолептичні показники, зокрема смак та запах.

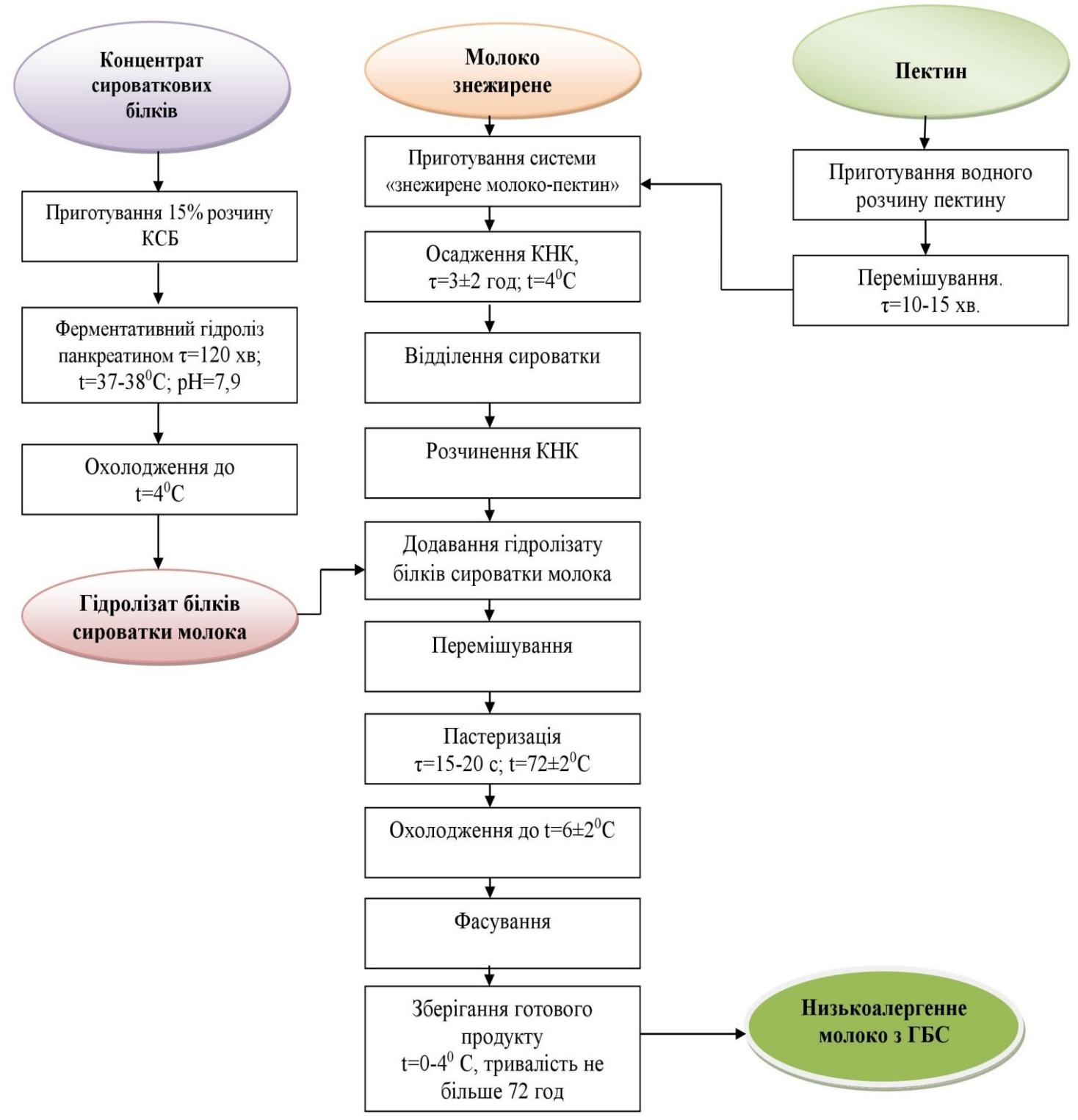

Рис. 4. Технологічна схема виготовлення низькоалергенного молока з гідролізатом білків сироватки 
Отримані електрофоретичні та хроматографічні дослідження свідчать про відсутність основних білків алергенів з сироватки молока. Це дозволяє рекомендувати продукт для харчування людей 3 алергією на білки сироватки молока.

\section{Висновки}

1. Розроблено технологію низькоалергенного молока з гідролізатом білків сироватки.

2. Задані умови отримання гідролізату забезпечують утворення природних біологічно активних пептидів з білків сироватки молока. Встановлено, що в отриманому гідролізаті відсутні білки алергени сироватки молока.

В подальшому необхідно детальніше охарактеризувати склад пептидів, ідентифікувати окремі пептиди та провести оптимізацію максимального виходу біологічно активних пептидів під час отримання гідролізату сироваткових білків.

\section{References}

Dekusha, H.V. (2009). Rozrobka tekhnolohii sukhykh sumishei $\mathrm{z}$ hidrolizovanym bilkom dlia dytiachoho kharchuvannia. dys....kand. tekhn. nauk: 05.18.16, Odesa (in Ukrainian).

Fox, P., Uniacke-Lowe, T., McSweeney, P., \& O'Mahony, J. (2015). Dairy Chemistry and Biochemistry. New York: Springer, 584. doi: 10.1007/978-3-319-14892-2.
Iukalo, A.V., Datsyshyn, K.Ye., \& Yukalo, V.G. (2013). Bioaktyvni peptydy proteiniv syrovatky moloka koriv (Bos taurus). Biotekhnolohiia Akta, 6, 49-61. doi: 10.15407/biotech6.05.049 (in Ukrainian).

Khramtsov, A.G. (2011). Fenomen molochnoy syvorotki. $\mathrm{SPb}$.: Professiya (in Russian).

Kim, H., Ahn, S.-I., Jhoo, Jin-Woo, \& Kim Gur-Yoo (2018). Comparison of Allergic Parameters between Whey Protein Concentrate and Its Hydrolysate in Rat Basophilic Leukemia (RBL)-2H3 Cells. Korean J. Food Sci. An, 38(4), 780-793. doi: 10.5851/kosfa.2018.e16.

McSweeney, P.L.H., \& Fox, P.F. (2013). Advanced Dairy Chemistry: Volume 1A: Proteins: Basic Aspects, 4th Edition. New York: Springer Science+Business Media. doi: 10.1007/978-1-4614-4714-6.

Villa, C., Costa, J., Oliveira, M.B.P.P., \& Mafra I. (2018). Bovine Milk Allergens: A Comprehensive Review. Comprehensive Reviews in Food Science and Food Safety, 17(1), 137-164. doi: 10.1111/1541-4337.12318.

Yukalo, V., Datsyshyn, K., \& Storozh, L. (2019). Electrophoretic system for express analysis of whey protein fractions. Eastern-European Journal of Enterprise Technologies, 2(11(98)), 37-44. doi: 10.15587/1729-4061.2019.160186.

Yukalo, V.G., Storozh, L.A., Datsyshyn, K.Ye., \& Krupa, O.M. (2018), Electrophoretic systems for the preparative fractionation of proteins-precursors of bioactive peptides from cow milk. Food science and technology, 12(2), 26-32. doi: 10.15673/fst.v12i2.932. 